\title{
Differential Distribution of Stem Cells in the Auditory and Vestibular Organs of the Inner Ear
}

\author{
Kazuo Oshima, ${ }^{1,2}$ Christian M. Grimm, ${ }^{1}$ C. Eduardo Corrales, ${ }^{1,2}$ Pascal,${ }^{3}$ enn, ${ }^{1}$ \\ Rodrigo Martinez Monedero, ${ }^{3}$ Gwenä̈lle S. G. Géléoc, ${ }^{4}$ Albert Edge, ${ }^{3}$ \\ Jefrerey R. Holt, ${ }^{4}$ and Stefan Heller ${ }^{1,2}$ \\ ${ }^{1}$ Departments of Otolaryngology_Head \& Neck Surgery and Molecular \& Cellular Physiology, Stanford University School \\ of Medicine, 801 Welch Road, Stanford, CA 94305-5739, USA \\ ${ }^{2}$ Marine Biological Laboratory, Woods Hole, MA 02543, USA \\ ${ }^{3}$ Department of Otolaryngology and Program in Neuroscience, Harvard Medical School and Eaton Peabody Laboratory, \\ Massachusetts Eye and Ear Infirmary, Boston, MA 02114, USA \\ ${ }^{4}$ Departments of Neuroscience and Otolaryngology, University of Virginia School of Medicine, Charlottesville, VA 22908, USA
}

Received: 25 August 2006; Accepted: 3 October 2006; Online publication: 14 December 2006

\begin{abstract}
The adult mammalian cochlea lacks regenerative capacity, which is the main reason for the permanence of hearing loss. Vestibular organs, in contrast, replace a small number of lost hair cells. The reason for this difference is unknown. In this work we show isolation of sphere-forming stem cells from the early postnatal organ of Corti, vestibular sensory epithelia, the spiral ganglion, and the stria vascularis. Organ of Corti and vestibular sensory epithelial stem cells give rise to cells that express multiple hair cell markers and express functional ion channels reminiscent of nascent hair cells. Spiral ganglion stem cells display features of neural stem cells and can give rise to neurons and glial cell types. We found that the ability for sphere formation in the mouse cochlea decreases about 100-fold during the second and third postnatal weeks; this decrease is substantially faster than the reduction of stem cells in vestibular organs, which maintain their stem cell population also at older ages. Coincidentally, the relative expression of developmental and progenitor cell markers in the cochlea decreases during the first 3 postnatal weeks, which is in sharp contrast to the vestibular system, where
\end{abstract}

Correspondence to: Stefan Heller • Departments of OtolaryngologyHead \& Neck Surgery and Molecular \& Cellular Physiology • Stanford University School of Medicine - 801 Welch Road, Stanford, CA 94305-5739, USA. Telephone: +1-650-7248086; fax: +1-650-7258502; email: hellers@stanford.edu expression of progenitor cell markers remains constant or even increases during this period. Our findings indicate that the lack of regenerative capacity in the adult mammalian cochlea is either a result of an early postnatal loss of stem cells or diminishment of stem cell features of maturing cochlear cells.

Keywords: cochlea, utricle, hair cell, regeneration, spiral ganglion, neurosphere

\section{INTRODUCTION}

The permanence of hearing loss is in most cases a result of the very limited regenerative capacity of the mammalian inner ear's sensory epithelia. Modest cellular regeneration of hair cells has been observed in rodent vestibular sensory epithelia (Forge et al. 1993; Warchol et al. 1993). In the adult mammalian cochlea, however, virtually no hair cell regeneration is detectable and attempted stimulation of dormant regenerative capacity has met with limited success (Corwin and Oberholtzer 1997; Feghali et al. 1998). Regenerated hair cells were occasionally identified, but only at very young postnatal ages, particularly in response to treatment with growth factors. These observations led to the general conclusion that the vestibular sensory epithelia and the auditory sensory epithelia have different regenerative capacities (Stone et al. 1998). A possible explanation for this difference is that the differentiated cell types that 
contribute to the highly specialized architecture of the organ of Corti lose proliferative and regenerative capacity during postnatal maturation of the auditory system (Lim and Rueda 1992; Kelley et al. 1995).

Cells with high proliferative capacity were recently isolated from adult mouse vestibular sensory epithelia ( $\mathrm{Li}$ et al. 2003a). A hallmark of these pluripotent vestibular stem cells is their ability to form clonal, free-floating colonies, called spheres. Hair cell progenitors have also been derived from the early postnatal rat cochlea (Malgrange et al. 2002; Zhai et al. 2005). To evaluate whether regenerative capacity of vestibular and cochlear tissues correlates with the presence of stem cells, we isolated sphere-forming stem cells at various ages from postnatal day 1 to 4 months of age. We found that during the first 3 postnatal weeks, all three cochlear tissues investigated-the organ of Corti, the spiral ganglion, and the stria vascularis-harbor sphere-forming cells that can be propagated for many generations, which is the defining feature of stem cells. Stem cells isolated from vestibular and cochlear sensory epithelia gave rise to hair cell-like cells with functional features that were distinctively similar to nascent hair cells. Spiral ganglion cell populations gave rise to neurospheres that could be differentiated into neurons and glial cell types. During the second and third postnatal weeks, the capacity for sphere formation was greatly reduced in cochlear tissues. In contrast, we were able to isolate stem cells from vestibular sensory epithelia from mice up to 4 months of age. Our results demonstrate the existence of stem cells in the cochlea of young mice and a sharp decline in their ability to generate spheres during the first 3 postnatal weeks. This decline is accompanied in cochlear tissues by a relative reduction of the expression levels for developmental and progenitor cell marker genes. Conversely, in utricular sensory epithelia, the expression of progenitor cell markers was sustained or even increased during the first 3 postnatal weeks. The loss of regenerative capacity of the mammalian cochlea therefore may be a direct consequence of the death of cochlear stem cells or a compromise in the genetic regulation of the self-renewal program during post- natal maturation of this organ. The latter explanation would validate continuing efforts to develop treatments for hearing loss aimed at reversing the mature differentiation status of adult cochlear cells.

\section{METHODS}

\section{Isolation of inner ear stem cells} and sphere formation

For each experiment, we dissected from three to four Math-1/nGFP mice (Lumpkin et al. 2003) the utricular maculae, saccular maculae, ampullary cristae, organs of Corti, spiral ganglia, and striae vascularis. Each organ was individually inspected, dissected from surrounding tissue, and carefully rinsed in Hank's balanced salt solution. Sensory epithelial sheets were isolated by treatment in $0.5 \mathrm{mg} / \mathrm{ml}$ thermolysin (Sigma) in DMEM/high glucose and F12 media (mixed 1:1, Invitrogen) (Corwin et al. 1995; Zheng et al. 1997). All tissues were collected in PBS at $\mathrm{pH}$ 7.4 on ice before they were subjected to a 10 - to 15 min digest with $0.125 \%$ trypsin in $\mathrm{PBS}$ at $37^{\circ} \mathrm{C}$ in a total volume of $100 \mu \mathrm{l}$. The enzymatic reaction was blocked by adding $50 \mu \mathrm{l}$ of $20 \mathrm{mg} / \mathrm{ml}$ soybean trypsin inhibitor and $2 \mathrm{mg} / \mathrm{ml}$ DNAse I solution (Worthington) in DMEM/high glucose and F12 media (mixed $1: 1$ ). The cells were carefully triturated with plastic pipette tips (epTIPS Filter 20-300 $\mu \mathrm{l}$; Eppendorf) and diluted with $2 \mathrm{ml} \mathrm{DMEM/high} \mathrm{glucose} \mathrm{and} \mathrm{F12}$ media (mixed 1:1) supplemented with N2 and B27 supplements (Invitrogen), EGF (20 ng/ml), bFGF $(10 \mathrm{ng} / \mathrm{ml})$, IGF-1 $(50 \mathrm{ng} / \mathrm{ml})$, and heparan sulfate (50 ng/ml) (growth factors obtained from Sigma). Cell separation was ensured via microscopic inspection. The cell suspension was then passed through a 70- $\mu \mathrm{m}$ cell strainer (BD Labware) directly into plastic Petri dishes (Greiner). This procedure generally yielded a completely dissociated single cell suspension virtually devoid of aggregates. Comparison of the total number of cells isolated per specimen showed no difference between $\mathrm{P} 1$ and $\mathrm{P} 42$ vestibular epithelia and stria vascularis (Table 1). Increasing ossification made the dissection of the organ of Corti

TABLE 1

Quantification of the total number of cells per specimen in inner ear tissues isolated from P1 and P42 mice

\begin{tabular}{lccc}
\hline & $\begin{array}{c}\text { Cell number per specimen } \\
\text { at P1 (mean } \pm \text { SD) }\end{array}$ & $\begin{array}{l}\text { Cell number per specimen } \\
\text { at P42 (mean } \pm \text { SD) }\end{array}$ & $P$ (Student's t-test) \\
\hline Utricle sensory epithelium & $2704 \pm 559$ & $3370 \pm 420$ & 0.174 \\
Stria vascularis & $43,222 \pm 5824$ & $41,333 \pm 6333$ & 0.723 \\
Organ of Corti & $101,555 \pm 2776$ & $34,444 \pm 4914$ & $<0.0005$ \\
Spiral ganglion & $195,777 \pm 6518$ & $140,222 \pm 20,331$ & 0.011 \\
\hline
\end{tabular}

Shown are the results from three independent experiments. 
and spiral ganglia more challenging at older ages, a fact that is reflected in the significant reduction of total cells to $34 \%$ (organ of Corti) and $74 \%$ (spiral ganglion) at P42 when compared to P1 (Table 1). In particular, the basal part of the organ of Corti is likely to be underrepresented in specimen taken from animals at P21 and older. In initial experiments, we plated the cells at very low density to ensure that spheres were formed from single cells according to previously reported methodology ( $\mathrm{Li}$ et al. 2003a). Routinely, we plated the total yield of single cells that we obtained from three to four inner ear organs into a single round 10-cm Petri dish. Note that the most noteworthy changes in this modified inner ear sphere-forming cell isolation protocol from the previously published protocol ( $\mathrm{Li}$ et al. 2003a) are the omission of two centrifugation steps, the use of soybean trypsin inhibitor, and the different combination of growth factors. Total numbers of primary spheres were assessed after 7 days in culture and related to the number of individual inner ear organs used in each experiment. For propagation, we collected 30-50 spheres after 5 days in culture and dissociated the cells by using the NeuroCult chemical dissociation kit (StemCell Technologies). The cell suspensions were replated in 10-cm Petri dishes and propagation was repeated in 5-day intervals. For longterm propagation, we counted the spheres of each generation, related the number to the original sphere number, and replated half of the spheres for generating the next generation. All animal studies were conducted under an approved institutional protocol according to National Institutes of Health guidelines.

\section{Cell differentiation}

For initiation of cell differentiation, we treated the spheres for $30 \mathrm{~s}$ with $0.05 \%$ trypsin to make them adherent and let them settle on cell culture-treated dishes coated with poly-L-ornithine and fibronectin (Sigma) in serum-free DMEM/high glucose and F12 media (mixed 1:1) supplemented with N2 and B27 supplements. Spiral ganglion-derived sphere cells were differentiated in the presence of $50 \mathrm{ng} / \mathrm{ml} \mathrm{NT}$ 3 and $100 \mathrm{ng} / \mathrm{ml}$ BDNF R\&D Systems to support neuronal differentiation and survival. Half of the medium was replaced every third day. Differentiated cells were analyzed after 14 days by immunocytochemistry. All cell differentiation results presented in this study were obtained from third-generation spheres.

\section{Immunocytochemistry}

The fixed cells were then incubated overnight at $4^{\circ} \mathrm{C}$ with diluted antibodies: 1:1000 for polyclonal guinea pig antibody to murine myosin VIIA (see below), 1:2000 for polyclonal rabbit antibody to parvalbumin 3 (Heller et al. 2002), polyclonal rabbit antibody to Musashil (courtesy of Dr. H. Okano, Keio University), polyclonal rabbit antibody to GFAP (Dako), monoclonal mouse antibody to neuron-specific $\beta$-III tubulin (TuJ, MMS-435P; Covance), and monoclonal mouse antibody to endothelial cell marker CD146 (MAB16985; Chemicon). Cy5-, tetramethylrhodamine isothiocyanate (TRITC)-, and fluorescein isothiocyanate (FITC)-conjugated antibodies (Jackson ImmunoResearch) were used to detect primary antibodies. DAPI (Molecular Probes) was used to visualize nuclei. A polyclonal antibody to murine myosin VIIA was generated in guinea pigs (Covance) by injecting affinity-purified hexahistidine-tagged myosin VIIA tail protein (amino acids 845-994), expressed in SF9 insect cells using the Gibco/BRL pFastBac baculovirus expression system. Cell counts were performed for each individual experiment $(n)$ by analyzing the total cell population from 20 to 40 individual spheres.

\section{RNA isolation and RT-PCR}

Total RNA was isolated from P1 and P21 Math-1/ nGFP mouse organ of Corti, utricle, spiral ganglion, and from 30 spheres and 30 differentiated spheres generated as described above, using RNeasy Mini Kits (Qiagen) and reverse-transcribed into cDNA with Superscript III (Invitrogen). Polymerase chain reaction (PCR) analysis was performed by using cDNA as template with the following oligonucleotides in PCR reactions conducted as described (Li et al. 2003a, b): glyceraldehydes-3-phosphate dehydrogenase (Gapdh) sense, 5'-AACGGGAAGCCCATCACCATCTT-3', Gapdh antisense, 5'-CAGCCTTGGCAGCACCAGTGG3'; Otx2 sense, 5'-CCATGACCTATACTCAGGCTT CAGG-3', Otx2 antisense, 5-GAAGCTCCATAT CCCTGGGTGGAAAG-3'; myosin VIIA sense, 5'CTCCCTCTACATCGCTCTGTTCG-3' , myosin VIIA antisense, 5'-AAGCACCTG CTCCTGCTCGTCCACG-3'; espin sense, 5'-CAGCCTGAGTCACCGCAGCCTC-3', espin antisense, 5'-TGACCTGTCGCTGC CAGGGCGCG-3'; Pax2 sense, 5'-CCAAAG TGGTGGA CAAGATTGCC-3', Pax2 antisense, 5'-GGATAGGAAG GACGCTCAAAG AC-3'; prestin sense, 5'-GCT GTCCTTTCCGCCATTGTGAT-3', prestin antisense, 5'-GGCCTTTCTTCTCGCTCCCATAA-3'; glial fibrillary acidic protein (GFAP) sense, 5'-CCTCCG CCAAGCCAAACACGAA-3', GFAP antisense, 5'ACCATCCCGCATCTCCACAGTC-3'; BMP4 sense, 5'TGGTAACCGAATGCTGATGGTCG-3', BMP4 antisense, 5'-GTCCAG TAGTCGTGTGATGAGGTG-3'; Brn3.1 sense, 5'-GCCATGCGCCGAGTTTGTCTCG-3', Brn3.1 antisense, 5'-ATGGCGCCTAGATGATGCGGGT-3'; peripherin sense, 5'-GTGAGCGTAGAGAGCCAGCAGG-3', peripherin 
antisense, 5'-TCGAAGCTCTTCCTCCAGCCGT-3'; Mcm2 sense, $5^{\prime}$-CTAATGGTGGCACGTTGGAGCC-3' ${ }^{\prime}$, Mcm2 antisense, 5'-CTT CTCAGGTATTT CAATGGTGTCC-3'; neurofilament-M (NF-M) sense, 5'-GCACATCACGGTA GAGCGCAAAG-3'， NF-M antisense， 5'-TCGTG CGCGCACTGGAATGCG-3' ${ }^{\prime}$; islet1 sense, $5^{\prime}$-CACCTTGCG GACCTGGTATGCC-3' ${ }^{\prime}$, islet1 antisense， 5'-GCTAC CATGCTGTTGGGTGTATC-3'. Cycle lengths for the different PCR reaction sets were adjusted between 25 and 32 cycles to achieve the best possible sensitivity.

\section{Electrophysiology}

Timed-pregnant female mice were anesthetized by exposure to $\mathrm{CO}_{2}$ and decapitated. The fetuses were removed at E15 and placed in MEM (Invitrogen). The utricular sensory epithelia were then excised from the embryo. To remove the otolithic membrane, the epithelia were treated with protease XXIV (Sigma) added at $0.1 \mathrm{mg} / \mathrm{ml}$ of MEM for $20 \mathrm{~min}$. Both the intact sensory epithelium and stem-cell derived cells were plated onto glass coverslips and bathed in a standard artificial perilymph solution that contained the following (in $\mathrm{mM}$ ): $144 \mathrm{NaCl}, 0.7$ $\mathrm{NaH}_{2} \mathrm{PO}_{4}, 5.8 \mathrm{KCl}, 1.3 \mathrm{CaCl}_{2}, 0.9 \mathrm{MgCl}_{2}, 5.6$ D- glucose, and 10 HEPES-NaOH, adjusted to $\mathrm{pH} 7.4$ and $320 \mathrm{mmol} / \mathrm{kg}$ osmolality. Recording pipettes were fabricated from borosilicate capillary glass (Garner Glass) with resistances of 2-4 M 2 . Pipette solutions contained (in $\mathrm{mM}$ ) $135 \mathrm{KCl}, 4 \mathrm{~K}_{4}$-EGTA, 10 HEPES, $3 \mathrm{Na}_{2} \mathrm{ATP}, 0.1 \mathrm{CaCl}_{2}$, adjusted to $\mathrm{pH}$ 7.4. Currents were recorded at room temperature (22$24^{\circ} \mathrm{C}$ ) by using an Axopatch 200B (Axon Instruments), filtered at $1 \mathrm{kHz}$ with an 8-pole Bessel filter (Krohn-Hite), digitized at $>4 \mathrm{kHz}$ with a 12-bit acquisition board and pClamp 8.0 (Axon Instruments) and analyzed with Origin 7.1 software (MicroCal). Data are presented as mean \pm SEM.

\section{RESULTS}

Sphere-forming cells from the inner ear's sensory epithelia, spiral ganglion, and stria vascularis

The discovery of stem cells in the adult mouse utricular sensory epithelium spurred our interest to investigate whether other parts of the inner ear also harbor stem cells that can be isolated by their ability to form spheres. We dissected from the auditory system of 3-week-old [postnatal day 21 (P21)] mice

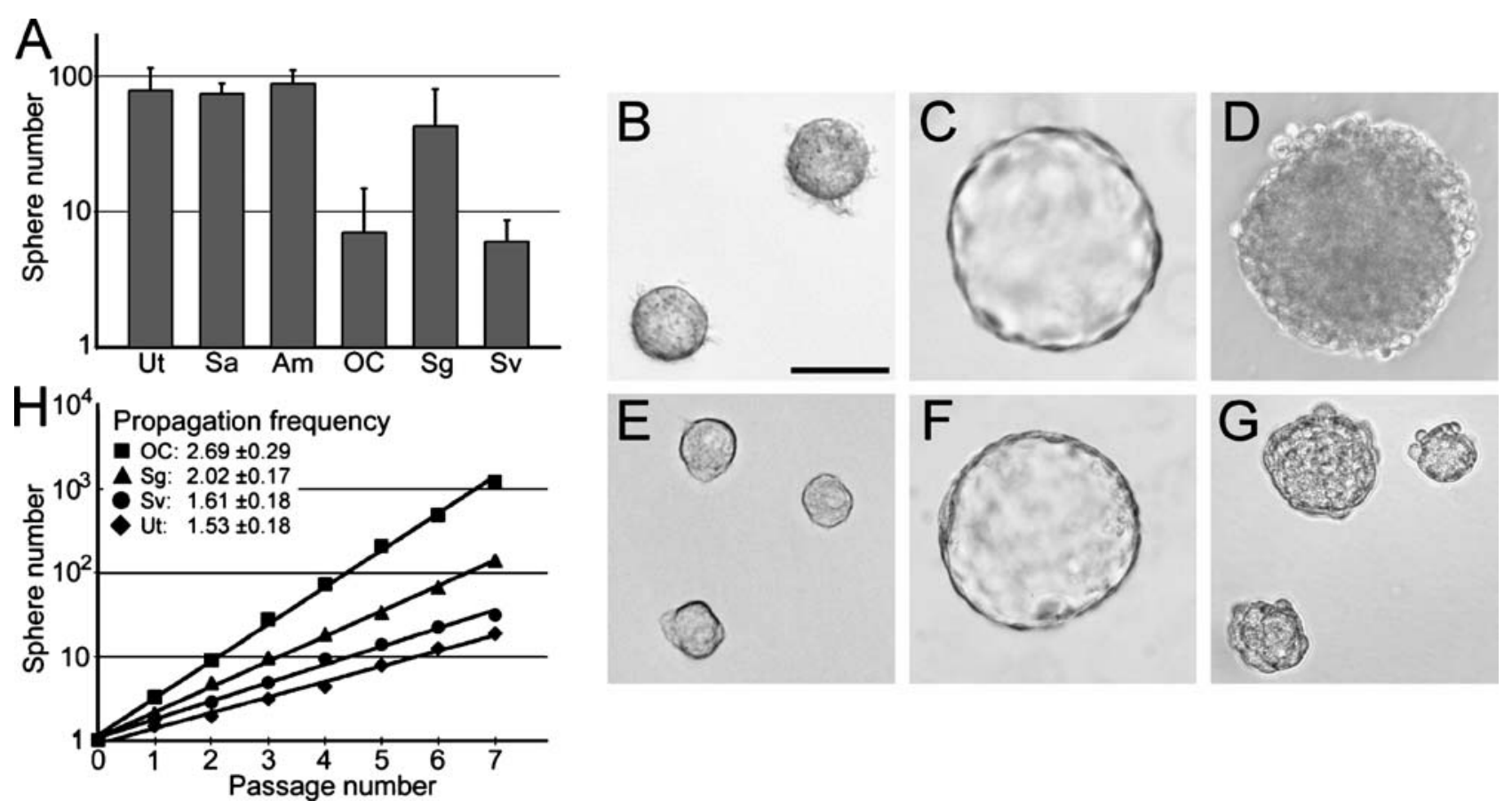

FIG. 1. Isolation of sphere-forming stem cells from the vestibular and auditory system of P21 mice. (A) Sphere formation after 7 days in vitro. Shown are mean numbers of spheres per specimen obtained in 3 independent experiments. The quantification shown is based solely on spheres with solid appearance. Error bars represent standard deviation (SD). A specimen is defined as a single epithelium from the utricle (Ut), sacculus (Sa), the combined three ampullae (Am), the organ of Corti (OC), one spiral ganglion (SG), and the stria vascularis (Sv). (B-G) Morphology of spheres isolated from various inner ear tissues. (B) Solid spheres from the utricle, (C) hollow spheres from the utricle, (D) sphere from the spiral ganglion, (E) solid spheres from the organ of Corti, (F) hollow sphere from the organ of Corti, and (G) solid spheres from the stria vascularis. (H) Propagation and expansion of spheres from utricle, organ of Corti, spiral ganglion, and stria vascularis. Shown is the logarithmic increase of total sphere number and the propagation frequency, defined as the average number of spheres derived from the dissociated cells of a single sphere \pm SD, $n=7$. Scale bar $=40 \mu \mathrm{m}$ in panels (B), (C), (E) $-(\mathrm{F})$ and $50 \mu \mathrm{m}$ in panel (D). 
the sensory epithelia of the organs of Corti, the spiral ganglia, and the striae vascularis. From each vestibular system, we isolated sensory epithelia from saccular maculae, ampullary cristae, and for comparison with our previous work (Li et al. 2003a), which focused on the utricle. We used an improved protocol that was based on a modification of our previously published method ( $\mathrm{Li}$ et al. 2003a) for generation of single cell suspensions (see Methods for details) and we ensured that the cells were completely dissociated by thorough microscopic inspection. Sphere formation was assessed after a 7-day culture period at moderate cell density in serum-free medium and we found sphere-forming capacity in all parts of the P21 inner ear examined (Fig. 1A). The vestibular sensory epithelia displayed the highest capacity for sphere formation; spheres from the cochlear tissues formed less frequently (Fig. 1A).

We also observed different sphere morphologies. Of the spheres, $66.3 \pm 3.1 \% \quad($ mean $\pm \mathrm{SD}, n=6)$ derived from vestibular and auditory sensory epithelia and $97.9 \pm 2.3 \%$ (mean $\pm \mathrm{SD}, n=3$ ) derived from spiral ganglia were solid in appearance, $50-100 \mu \mathrm{m}$ in diameter (Table 2), and without obvious hollow spaces (Fig. 1B,D,E,G). A significant portion $(32.9 \pm 3.3 \% ; n=6)$ of the spheres found in preparations from vestibular or auditory sensory epithelia was freely floating hollow spheres of up to $200 \mu \mathrm{m}$ in diameter (Fig. 1C,F). Solid spheres derived from cochlear tissues were generally larger and contained more cells than spheres obtained from vestibular sensory epithelia (Table 2).

\section{Solid spheres arise from stem cells}

The defining feature of a stem cell is its ability to selfrenew (McKay 1997). To test for self-renewal, we dissociated solid and hollow primary spheres

\section{TABLE 2}

Characteristics of solid spheres isolated from P1 and P21 tissues

\begin{tabular}{llc}
\hline & $\begin{array}{l}\text { Diameter in } \\
\mu m( \pm S D)\end{array}$ & $\begin{array}{l}\text { Cell number per } \\
\text { sphere }( \pm S D)\end{array}$ \\
\hline P1 Utricular macula & $59.1 \pm 15.2$ & $33.0 \pm 12.1$ \\
P1 Saccular macula & $58.0 \pm 17.2$ & $36.9 \pm 8.8$ \\
P1 Ampullary crista & $62.0 \pm 15.1$ & $33.2 \pm 12.3$ \\
P1 Organ of Corti & $68.5 \pm 24.9$ & $299.1 \pm 101.7$ \\
P1 Spiral ganglion & $94.3 \pm 30.5$ & $247.8 \pm 69.6$ \\
P1 Stria vascularis & $73.5 \pm 30.9$ & $120.7 \pm 30.8$ \\
P21 Utricular macula & $40.9 \pm 13.5$ & $32.0 \pm 10.2$ \\
P21 Saccular macula & $42.0 \pm 6.9$ & $40.3 \pm 11.8$ \\
P21 Ampullary crista & $42.9 \pm 15.0$ & $28.7 \pm 9.2$ \\
P21 Organ of Corti & $74.3 \pm 24.7$ & $171.0 \pm 41.2$ \\
P21 Spiral ganglion & $71.6 \pm 11.1$ & $201.5 \pm 56.7$ \\
P21 Stria vascularis & $64.6 \pm 22.2$ & $47.7 \pm 11.7$ \\
\hline
\end{tabular}

obtained from P21 mice inner ear tissues and maintained the resulting cells under conditions identical to those used for the initial sphere generation. We found that all solid sphere populations could be maintained and propagated with a constant ratio of 1.5-2.7 new spheres per propagated sphere per generation (Fig. 1H). This assessment corroborates our previous determination that a single stem cell-generated sphere from the adult mouse utricle contains 2-3 sphere-forming stem cells ( $\mathrm{Li}$ et al. 2003a). Although hollow spheres displayed an initial capacity for propagation, it was not possible to maintain these cell populations beyond the third generation (data not shown).

\section{Differentiation of mature inner ear cell types}

It has been previously demonstrated that mature inner ear cell types differentiate from progeny of spheres derived from the adult utricle ( $\mathrm{Li}$ et al. 2003a) and early postnatal cochlea (Malgrange et al. 2002). We have also previously demonstrated that utricle-derived spheres are of clonal origin ( $\mathrm{Li}$ et al. 2003a). We now show that other parts of the inner ear also harbor sphere-forming stem cells (Fig. 1), and we sought to test the hypothesis that spheres from different origins will vary in their ability to spontaneously generate mature inner ear cell types. We adhered third-generation spheres and cultured the cells for 2 weeks in serum-free medium with defined medium supplements. These conditions have been shown to be sufficient for hair cell and neural differentiation from utricle-derived spheres (Li et al. 2003a).

Using reverse transcription (RT)-PCR, we monitored the relative expression levels of markers that are expressed in embryonic and mature inner ear cell types (Fig. 2). Generally, we found low or no expression of mature cell markers in all sphere populations that we investigated. For example, the hair cell markers Brn3.1, myosin VIIA, and espin (Sahly et al. 1997; Xiang et al. 1997; Zheng et al. 2000b) were not detectable in spheres derived from the utricle and organ of Corti, but all markers were up-regulated after adherence of the spheres and 2 weeks culture under differentiation conditions. Organ of Corti-derived spheres gave rise to a population of cells that expressed the outer hair cell marker prestin (Zheng et al. 2000a). Although low-level expression of prestin has been previously observed in the vestibular system (Adler et al. 2003), the sensitivity of our method did not suffice to reveal prestin expression in the utricle. In spiral ganglionderived neurospheres, we detected expression of the neuronal stem cell marker Mcm2 (Maslov et al. 2004), which was also expressed in neonatal spiral 


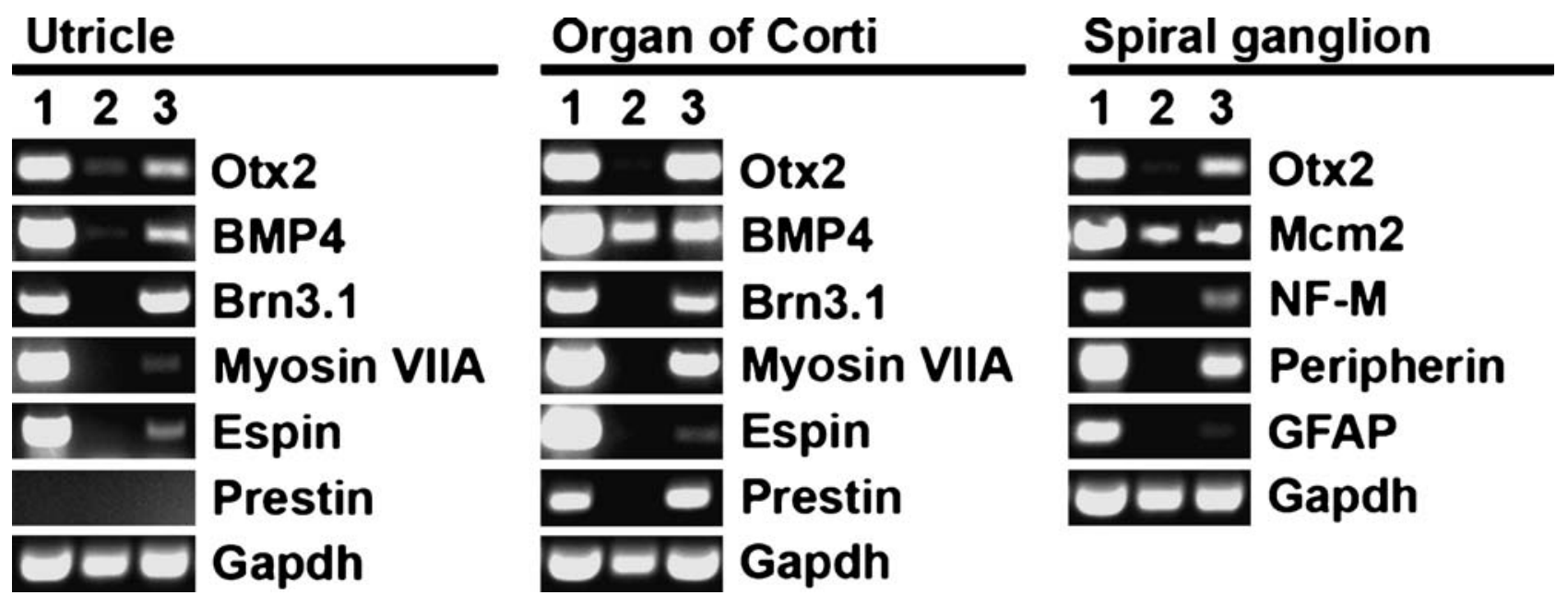

FIG. 2. RT-PCR analysis of expression of markers for developing and mature inner ear cell types in early postnatal P1-P3 inner ear organs (lane 1), spheres derived from these organs (lane 2), and differentiated cell populations (lane 3). Glyceraldehyde-3-phosphate dehydrogenase (Gapdh) expression analysis is shown as reference.

ganglion tissue. Markers for mature neurons, neurofilament-M and peripherin, which is expressed by type-II spiral ganglion neurons (Hafidi 1998), and for glia (glial fibrillary acidic protein) were detectable after differentiation of spiral ganglion-derived spheres. Mature markers for hair cells were not detectable in the spiral ganglion sphere-derived population of cells (data not shown).

Because of the inherent heterogeneity of stem cellderived spheres (Suslov et al. 2002), RT-PCR is suitable to only a limited extent for analysis of expression of markers in sphere-derived cell populations. We consequently used antibodies to demonstrate expression of hair cell and neural marker proteins in differentiated sphere-derived cells. In $15.6 \pm 6.1 \% \quad($ mean $\pm \mathrm{SD}, n=16) \quad$ third-generation sphere cell populations from auditory (Fig. 3A-F) and vestibular (Fig. 5) sensory epithelia differentiated for 2 weeks, we found $3.6 \pm 1.4 \%$ (mean $\pm \mathrm{SD}$, $n=12$ ) cells that coexpressed the hair cell markers myosin VIIA and parvalbumin 3. We never encountered cells that were immunopositive for only one of the two markers. Overall, $0.57 \pm 0.22 \%$ (mean \pm SD, $n=12$ ) of the total cells were double-positive for myosin VIIA and parvalbumin 3. In addition, $43.7 \pm 18.3 \%$ (mean $\pm \mathrm{SD}, n=12$ ) of cells with nuclear green fluorescence (nGFP) displayed expression of myosin VIIA and parvalbumin 3. nGFP expression is an indication of activation of the enhancer for the Atoh1 gene encoding Math1, a key transcription factor for hair cell development (Bermingham et al. 1999; Helms et al. 2000; Lumpkin et al. 2003) (Figs. 3C-F and 4). The transgenic nGFP/Math1 mice used in our study exhibit strong nuclear green fluorescence in vestibular and cochlear hair cells (Lumpkin et al. 2003). None or only a few nGFP-positive cells were detectable immediately after attaching spheres from auditory and vestibular epithelia; the number of nGFP-positive cells was increased after 5 days in culture and the number of nGFP-positive cells increased further after 2 weeks (Fig. 3G). It is conceivable that nascent hair cells in the differentiating sphere cell populations are first recognizable by nGFP (Atoh1) expression, followed by up-regulation of other hair cell markers, a progression of marker gene expression that reflects native hair cell development (Chen et al. 2002).

Although we found a few cells expressing neural markers in differentiated spheres from the organ of Corti and vestibular sensory epithelia (data not shown; $\mathrm{Li}$ et al. 2003a), the highest number of neurons $(1.4 \pm 0.45 \%$; mean $\pm \mathrm{SD}, n=9)$ occurred in differentiated spiral ganglion neurospheres (Fig. $3 \mathrm{H}$ ). The ratio of neurons vs. nonneuronal cells is probably shifted toward nonneuronal cells, which continued to proliferate during the 2-week differentiation period (data not shown). Occasionally $(<0.1 \%)$, we found single nGFP, myosin VIIA, and parvalbumin 3 triplepositive hair cell-like cells in differentiated spiral ganglion neurosphere populations (data not shown). The expression of marker proteins correlated with the morphology of the differentiated cells. Spheres from the organ of Corti or any vestibular sensory epithelia formed dense epithelial-like patches of cells (Fig. 3I,J), whereas many cells with neural morphology were visible in spiral ganglion neurospherederived populations (Fig. 3K). Even though cells derived from strial spheres appeared to adopt a mature morphology (Fig. 3L), we did not detect expression of the endothelial marker CD146 or up- 


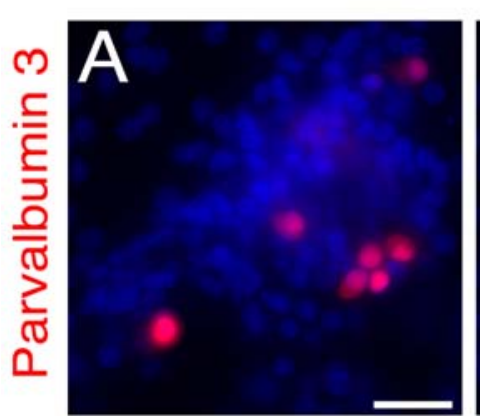

\section{Myosin VIIA}
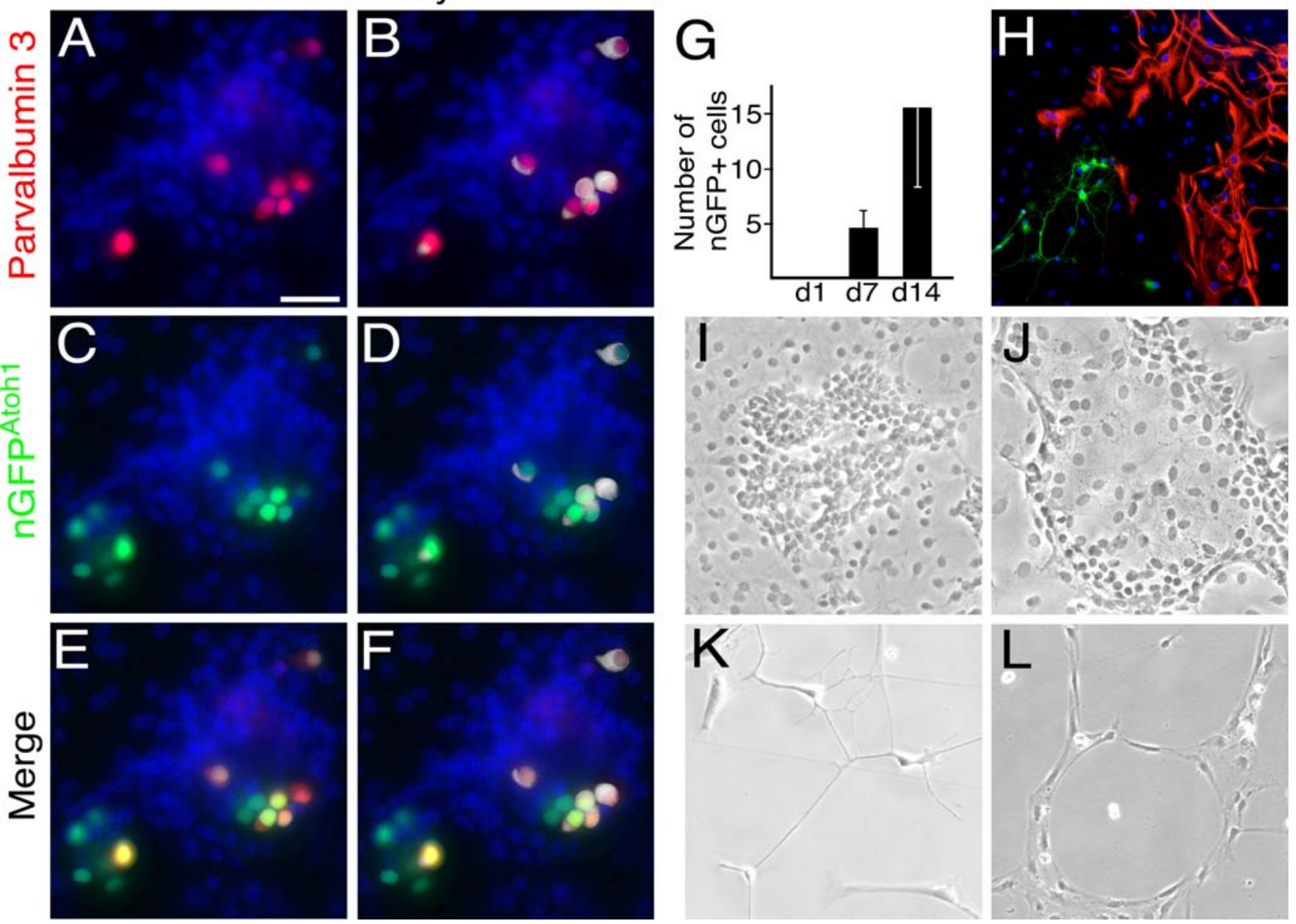

FIG. 3. Differentiation of cochlear stem cell-derived cell populations. (A-F) After a 2-week differentiation, hair cell-like cells appeared in cells derived from an organ of Corti-derived sphere. Note that all cells immunopositive for parvalbumin 3 (detected with TRITC-conjugated secondary antibody, depicted in red) also expressed myosin VIIA (detected with Cy5-conjugated secondary antibody, depicted in white) and displayed nuclear green fluorescence, an indication for activated Atoh1 promoter. All cell nuclei are visualized with DAPI (shown in blue). (G) Time course of appearance of nGFP-positive cells in organ of Corti sensory epithelia-derived sphere populations after initiation of cell differentiation. Shown are the mean \pm SD of five midsize spheres differentiated for 14 days. $(\mathrm{H})$ Differentiating cell populations from spiral ganglion-derived spheres contain cells with neuronal morphology that are immunopositive for neuron-specific $\beta$-III tubulin (detected with FITC-conjugated secondary antibody, shown in green) and glial fibrillary acidic protein (GFAP, detected with Cy5-conjugated secondary antibody, depicted in red). Cell nuclei are visualized with DAPI (shown in blue). (I) Light microscopic visualization of an attached utricle-derived sphere after 2 weeks of differentiation. (J-L) Same as (I), but with organ of Corti (J), spiral ganglion (K), and stria vascularis-derived (L) spheres.

regulation of mRNAs for mature strial cell types, indicating that the conditions used were not sufficient to induce in vitro differentiation of distinct strial inner ear cell types (data not shown). We did not detect any cells that are immunopositive for hair cell or neuronal markers in strial sphere-derived differentiated cell populations.

Stem cell-derived hair cell-like cells display functional properties of nascent hair cells

We have previously reported that hair cell-like cells that differentiate from vestibular epithelium-derived spheres display hair bundlelike protrusions that are immunopositive for hair bundle markers (Li et al. 2003a). Hair cell-like cells with similar morphology were also visible in differentiated cell populations analyzed in this study (Fig. 4A shows hair cell-like cells derived from sacculus-derived spheres). This apparent morphological maturation into nascent hair cells raised the question whether stem cellderived hair cell-like cells display functional properties of hair cells. Hence, we tested for the presence of voltage-dependent conductances in nGFP-positive cells differentiated from utricle-derived spheres. We chose utricle-derived spheres for this experiment because it was possible to compare the results with data derived from native embryonic vestibular hair cells (Géléoc et al. 2004). Hair cells of the developing mouse utricle undergo a stereotyped pattern of phy- 

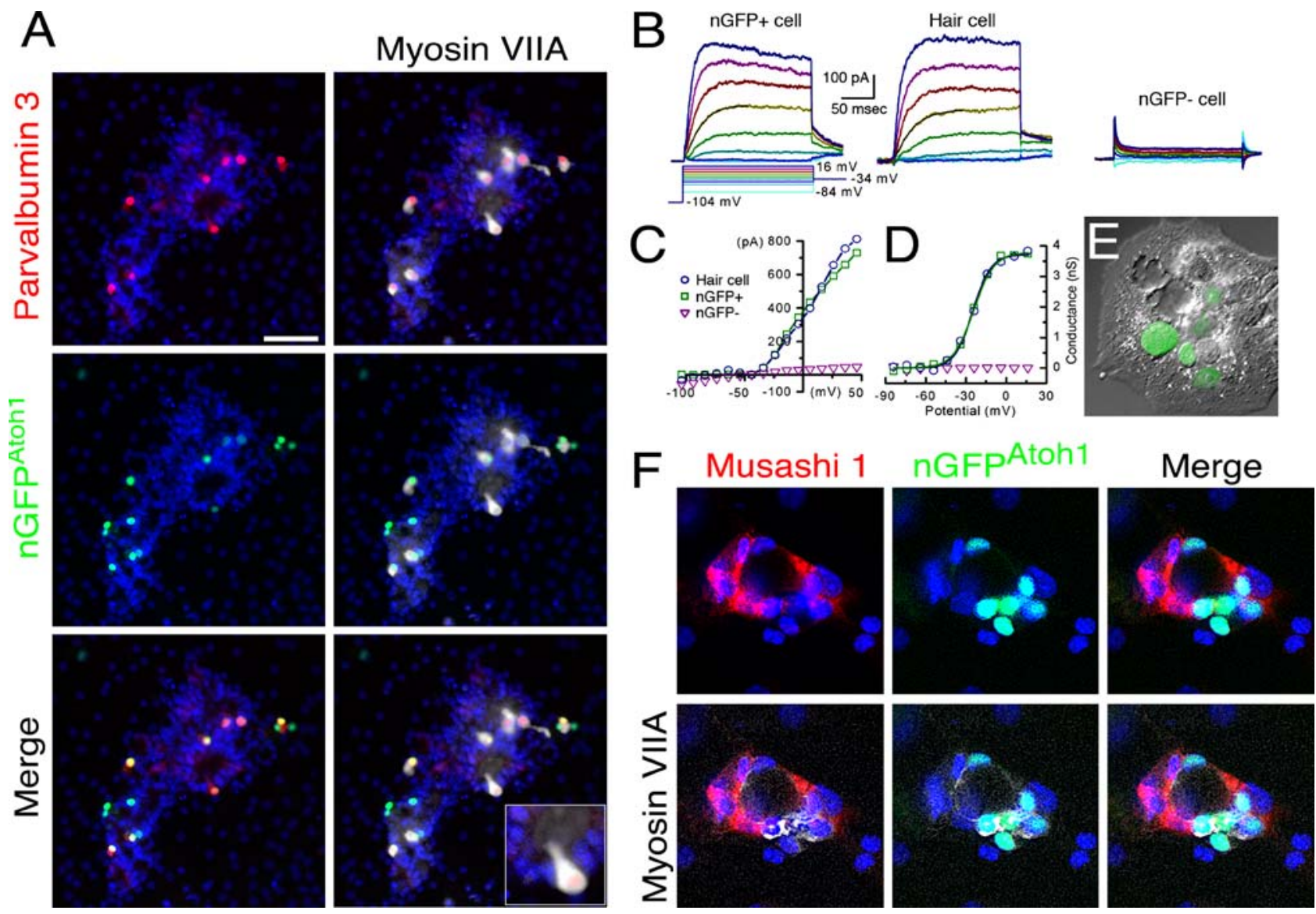

FIG. 4. Differentiation of vestibular epithelium and organ of Corti stem cell-derived cell populations. (A) After 2 weeks of differentiation culture, hair cell-like cells appear in differentiating cells derived from a sacculus-derived sphere. Note that all cells immunopositive for parvalbumin 3 (detected with TRITC-conjugated secondary antibody, depicted in red) also expressed myosin VIIA (detected with Cy5conjugated secondary antibody, depicted in white) and displayed nuclear green fluorescence, an indication of Atoh1 promoter activation. All cell nuclei are visualized with DAPI (shown in blue). The inset shows a higher magnification of a hair cell-like cell with a myosin VIIA-positive protrusion similar to hair bundlelike structures previously observed (Li et al., 2003a). Scale bar $=50 \mu \mathrm{m}$. (B) Voltage-dependent currents from a representative stem cell-derived nGFP-positive cell, an E15 mouse utricular hair cell, and a representative nGFP-negative cell. The voltage protocol is shown below the traces. The scale bar applies to all three families. (C) Peak current-voltage relations taken from the data shown in (B) for the stem cell-derived cell (blue circles), for an E15 hair cell (green squares), and an nGFP-negative, stem cell-derived cell (magenta triangles). (D) Activation curve derived from the data shown in (B) and (C), fitted independently with a first-order Boltzmann equation. (E) Merged DIC/fluorescence image of stem cell-derived cells harvested from nGFP/Math1 mouse utricles and in vitro-differentiated for 6 days. (F) Hair cell-like cells differentiated from organ of Corti-derived spheres are associated with cells that display cytoplasmic distribution of Musashi1. After a 2-week differentiation, myosin VIIA-immunopositive hair cell-like cells (detected with Cy5-conjugated secondary antibody, depicted in white) that coexpress nGFP (indicative of expression of Math1) can be found in close vicinity of cells with cytoplasmic immunoreactivity for Musashi1 (detected with TRITC-conjugated secondary antibody, shown in red). All cell nuclei are visualized with DAPI (shown in blue).

siological development beginning as early as embryonic day 13 (Géléoc et al. 2004). Using the tight-seal, whole-cell recording technique, we analyzed 10 stem cell-derived cells from spheres that were originally harvested from P42 nGFP/Math1 mouse utricles. Directly after attaching the spheres to gelatin-coated coverslips, no nGFP-positive cells were present, indicating that no surviving hair cells were present in the cell populations. After 6-9 days in culture, we observed many GFP-positive cells (Fig. 4E) that presumably expressed Math1 and were thus destined to become hair cells. We used a family of 200-ms voltage steps that ranged from -104 to $46 \mathrm{mV}$ in 10 -
$\mathrm{mV}$ increments to evoke voltage-dependent currents. The steps were preceded by a 100- ms step to -104 $\mathrm{mV}$ to relieve voltage-dependent inactivation. We were unable to evoke voltage-dependent currents in any of the four GFP-negative cells that we analyzed (Fig. 4B-D). In 6 of 6 nGFP-positive cells, depolarization evoked activation of outward currents that resembled the delayed rectifier potassium currents of embryonic hair cells (Géléoc et al. 2004). A family of potassium currents recorded from a representative stem cell-derived cell is shown in Figure 4B. For comparison, a representative family of currents from an embryonic hair cell excised at E15 is also shown 
(Fig. 4B). The time dependence of current activation was similar for the two cells. We fit current activation with a double exponential equation that has been used to describe the activation of potassium currents in postnatal vestibular hair cells (Rusch et al. 1998). For the step to $-14 \mathrm{mV}$, the time constants of the fits for the GFP-positive stem cell-derived cell were 6.0 and $22.1 \mathrm{~ms}$, remarkably similar to those for the E15 hair cell (6.3 and $22.8 \mathrm{~ms}$ ). On average, the time constants for the six stem cell-derived cells were $7.4 \pm 2.9$ and $27 \pm 4.8 \mathrm{~ms}$, similar to the mean values from the embryonic hair cells: $5.4 \pm 3.3$ and $21 \pm 2 \mathrm{~ms}$ $(n=6)$. Figure $4 \mathrm{C}$ shows the peak current-voltage relationship from the two cells shown in Figure 4B, as well as the $I(V)$ relation from one of the four GFPnegative stem cell-derived cells all of which lacked voltage-dependent currents. To examine the voltage dependence, we measured tail currents at the instant of the step to $-34 \mathrm{mV}$, which followed the family of steps shown in the protocol (Fig. 4B). The tail currents were divided by driving force to yield conductance and fitted with a first-order Boltzmann equation, which revealed remarkable similarity between the nGFP-positive cells and hair cells. In the examples shown in Figure 4, the voltage of halfmaximal activation ( $V_{\text {half }}$ ) was -25 and $-24 \mathrm{mV}$ for the stem cell-derived cell and the E15 hair cell, respectively, and the steepness of the curves was 6.8 and $7.5 \mathrm{mV}$ (Fig. 4D). On average, the $V_{\text {half }}$ for the six GFP-positive stem cells was $-29 \pm 2 \mathrm{mV}$ with a steepness of $6.4 \pm 0.3 \mathrm{mV}$. In a previous study, Géléoc et al. (2004) reported that the mean $V_{\text {half }}$ for the outward rectifier potassium conductance was $-28.7 \pm 5.5 \mathrm{mV}$ with a mean slope of $6.1 \pm 1.7 \mathrm{mV}$ in a sample of 80 embryonic hair cells. The mean maximal conductance for the six stem cell-derived cells was $3.0 \pm 0.6$ $\mathrm{nS}$, which closely paralleled the mean conductance for E15 hair cells reported previously $(3.9 \pm 1.1 ; n=6)$ (Géléoc et al. 2004). In summary, the magnitude, kinetics, voltage dependence, and voltage range of activation of the currents we recorded from nGFPpositive cells resembled the potassium currents of 3day-old hair cells acutely excised from the mouse utricle at E15 and were strikingly different from the currents measured from nGFP-negative stem cellderived cells.

Another indication of the immature status of differentiated sphere cell populations arises from the expression of Musashi1, an RNA binding protein associated with asymmetric cell divisions (Imai et al. 2001; Murata et al. 2004). Cells with strong cytoplasmic Musashi1-immunoreactivity were often juxtaposed to hair cell marker-positive cells that did not express Musashi1 [Fig. 4F shows organ of Cortiderived cells; we observed similar Musashi1 expression in utricle-derived cells (not shown)]. In the developing organ of Corti, Musashi1 is not detectable in cochlear hair cells. In embryonic cochlear supporting cells, Musashil is initially localized in the cytoplasm before the protein is redistributed into the nucleus during the first 2 postnatal weeks (Sakaguchi et al. 2004). The cytoplasmic location and expression of Musashil in cells surrounding hair cell-like cells in our cultures is therefore reminiscent of immature supporting cells.

\section{Cochlear organs lose the capacity for sphere formation during the third postnatal week}

The relatively low number of stem cells in the P21 cochlea, when compared with vestibular organs (Fig. 1A), attracted our interest whether more sphere-forming cells could be found at younger ages. We therefore tested inner ear tissue isolated at postnatal day 1 (P1), $\mathrm{P} 4, \mathrm{P} 7$, and $\mathrm{P} 14$. We also used specimens isolated from P42 and P120 mice to assess whether the capacity for sphere formation in inner ear tissues declines in animals older than P21.

In vestibular sensory epithelia, we found the highest number of sphere-forming cells at P1 and we observed a steady decline in the number of sphere-forming cells
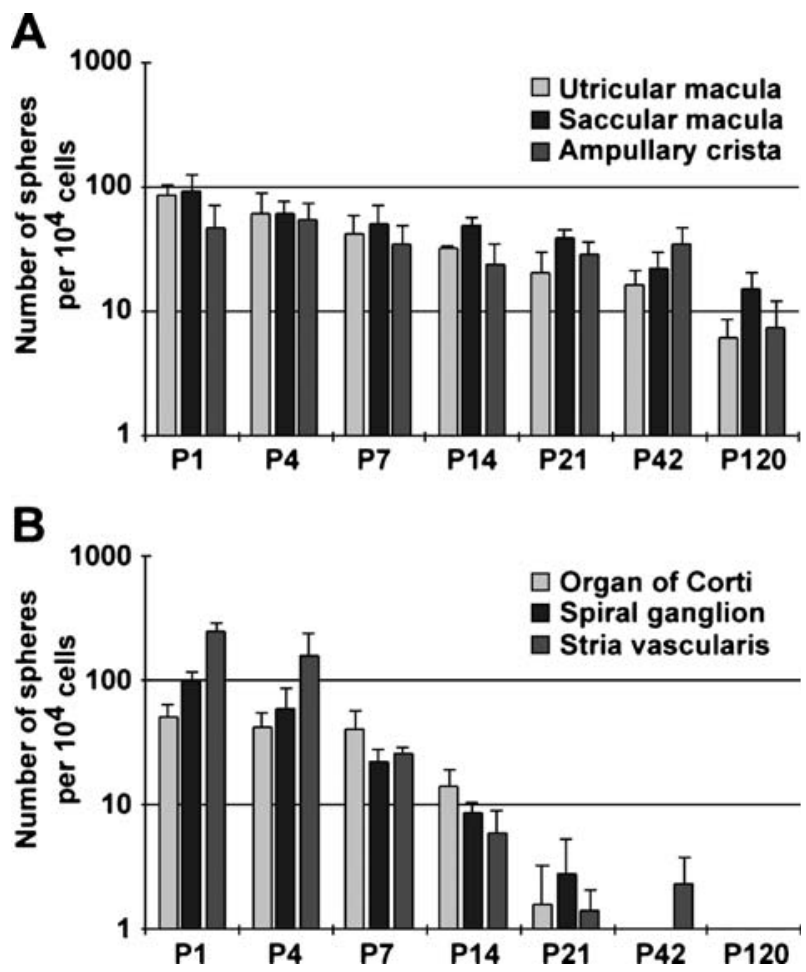

FIG. 5. Quantification of sphere-forming stem cells in (A) vestibular sensory epithelia and in (B) cochlear tissues from birth to adulthood. Shown is the number of primary solid spheres per $10^{4}$ cells after complete tissue dissociation that formed after 7 days in serum-free culture in nonadherent Petri dishes (mean $\pm S D, n=3$ ). Table 3 displays the actual values shown in the figure. 
TABLE 3

Number of primary solid spheres per $10^{4}$ cells that formed after 7 days in serum-free culture in nonadherent Petri dishes $($ mean $\pm \mathrm{SD}, n=3)$

\begin{tabular}{|c|c|c|c|c|c|c|c|}
\hline & P1 & $P 4$ & $P 7$ & P14 & $P 21$ & P42 & P120 \\
\hline tricular macula & $4.14 \pm 16.53$ & $59.72 \pm 27.04$ & $41.83 \pm 16.62$ & $1.22 \pm 2.21$ & $20.02 \pm 9.34$ & $16.04 \pm 4.52$ & $5.95 \pm 2.63$ \\
\hline Saccular macula & $89.52 \pm 34.05$ & $59.43 \pm 14$ & $49.54 \pm 19.34$ & $48.05 \pm$ & 7.21 & $21.97 \pm 7.05$ & $14.66 \pm 5.44$ \\
\hline Ampullary crista & $45.44 \pm 22.92$ & $53.04 \pm 19.47$ & $33.50 \pm 15.08$ & $23.81 \pm 10.69$ & $28.07 \pm 7.40$ & $34.55 \pm 12.07$ & $7.18 \pm 4.54$ \\
\hline Organ of Corti & $50.74 \pm 10.90$ & $41.91 \pm 12.46$ & $40.20 \pm 15.99$ & $13.84 \pm 4.75$ & $1.55 \pm 1.72$ & $0.27 \pm 0.47$ & 0.00 \\
\hline Spiral ganglion & $97.00 \pm 16.40$ & $58.87 \pm 26.37$ & $22.13 \pm 5.15$ & $8.48 \pm 1.98$ & $2.80 \pm 2.44$ & $0.07 \pm 0.11$ & 0.00 \\
\hline Stria vascularis & $239.00 \pm 45.80$ & $156.19 \pm 76.28$ & $25.54 \pm 3.06$ & $5.83 \pm 3.13$ & $1.43 \pm 0.63$ & $2.30 \pm 1.44$ & 0.00 \\
\hline
\end{tabular}

throughout the time period tested (Fig. 5A; Table 3). However, even at the oldest age tested, we observed a considerable number of sphere-forming stem cells.

In cochlear tissues, we found that dissociated cells from the organ of Corti, the spiral ganglion, and the stria vascularis gave rise to an ample sphere population at P1 and P4 (Fig. 5B). Whereas the organ of Corti contained a sizable number of sphere-forming cells at P7, sphere formation was starkly reduced in cell populations isolated from P7 spiral ganglion and stria vascularis. The organ of Corti appears to lose the majority (about 100-fold) of its capacity to generate spheres between P7 and P21, whereas spiral ganglionderived spheres were still detectable at P21, but not at P42. Sphere formation from organ of Corti-derived tissue was virtually absent at $\mathrm{P} 42$.

\section{TABLE 4}

Comparison of the number of spheres formed from P1 inner ear tissue isolated immediately after decapitation and after a 2-h delay

\begin{tabular}{lccc}
\hline & $\begin{array}{l}\text { Number of } \\
\text { spheres per } \\
\text { specimen } \\
\text { (mean) }\end{array}$ & $\begin{array}{l}\text { Standard } \\
\text { deviation }\end{array}$ & $P$ (Student's t-test) \\
\hline $\begin{array}{l}\text { Immediate } \\
\text { dissection } \\
\text { (Utricle) }\end{array}$ & 245 & 32.6 & 0.343 \\
2 h delayed \\
$\begin{array}{l}\text { dissection } \\
\text { (Utricle) }\end{array}$ & 217 & 29.7 & \\
$\begin{array}{l}\text { Immediate } \\
\text { dissection } \\
\text { (Organ of Corti) }\end{array}$ & 756 & 73.7 & 0.366 \\
2 h delayed \\
$\begin{array}{l}\text { dissection } \\
\text { (Organ of Corti) }\end{array}$ & 679 & 109 & \\
$\begin{array}{l}\text { Immediate } \\
\text { dissection } \\
\text { (Spiral ganglion) }\end{array}$ & 1667 & 96 & 0.08 \\
2 h delayed \\
$\begin{array}{l}\text { dissection } \\
\text { (Spiral ganglion) }\end{array}$ & 1285 & 266 & \\
\hline
\end{tabular}

Shown are the results from three independent experiments.
We performed a number of control experiments to exclude the possibility that the observed loss of sphere-forming cells in cochlear tissues is not a result of the disproportionate effects on the stem cell population caused by increasing difficulty and time required for cell isolation. First, we measured the total time needed for dissecting and for cell separation of all six organs from individual mice at postnatal days 1 and 42 ( $\mathrm{P} 1$ and $\mathrm{P} 42$ ). Total time from decapitating the animals until the cells were placed into the incubator was $71 \pm 4$ min for P1 mice and $87 \pm 7$ min for P42 mice (mean \pm SD, $n=3$ for both). In a second series of experiments, we dissected temporal bones from littermates and compared the efficacy of sphere formation between preparations that were done immediately and preparations that were kept in ice-cold buffer for $2 \mathrm{~h}$ before commencing with the cell separation. We found that the number of spheres that formed differed only minimally and not significantly between the two preparations (Table 4), which is an indication that sphere formation is not greatly affected by small differences in processing time.

Developmental and progenitor cell markers decrease in maturing cochlear organs but remain stable or increase in maturing vestibular epithelia

The stark reduction of the capacity of cochlear organs to generate spheres during the first 3 postnatal weeks raises the question whether this loss of regenerative capacity is reflected in the expression levels of marker genes for progenitor cells. Indeed, we found that relative expression levels of the considerable majority of progenitor and stem cell markers that we investigated was reduced when we compared P1 organ of Corti and spiral ganglion with P21 tissues (Fig. 6). In contrast, the mRNA expression of all progenitor and stem cell markers investigated were stably maintained or even increased during that period in utricular sensory epithelium (Fig. 6). This differences in dynamic changes of gene 


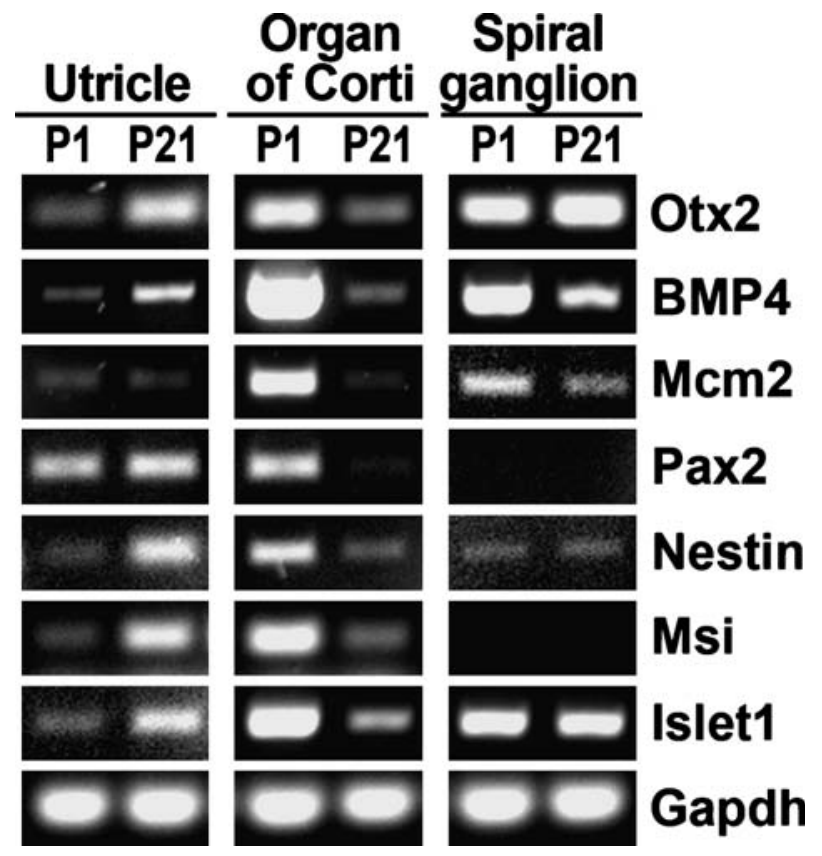

FIG. 6. RT-PCR analysis of expression of developmental and progenitor cell markers in the P1 and P21 utricle sensory epithelium, the organ of Corti, and the spiral ganglion. Msi=Musashi1. Gapdh expression analysis is shown as reference.

expression is particularly obvious when we compare the expression of the stem cell and inner ear developmental markers Otx2 (Morsli et al. 1999; Sanchez-Calderon et al. 2002), Mcm2 (Maslov et al. 2004), nestin (Lendahl et al. 1990; Rietze et al. 2001), and Musashi1 (Maslov et al. 2004; Sakaguchi et al. 2004). Another indication for a different status of the regenerative potential between cochlear and vestibular tissues is the antidromic expression of BMP4 and Pax2, genes that are important for inner ear sensory patch development (Oh et al. 1996; Li et al. 2004a, 2005) as well as islet-1, a gene expressed in developing sensory epithelia and cochlear and vestibular ganglion neurons (Li et al. 2004b).

\section{DISCUSSION}

We draw two major conclusions from our results: first, that the different areas of the murine inner ear harbor stem cells that are intrinsically different and second, that, contrary to the vestibular system, the auditory part of the inner ear loses the vast majority of stem cells between the second and third postnatal weeks. Our tests show that sphere-forming cells isolated from the various inner ear sensory epithelia, the spiral ganglion, and the stria vascularis, possess high proliferative potential and the capacity for selfrenewal. This capacity for self-renewal and the ratio of 1-3 next-generation spheres generated from a single sphere is evidence for the presence of 1-3 stem cells in each sphere, a feature that allowed us to propagate and expand sphere populations from all inner ear organs investigated in this study. Whereas initial sphere formation and the dynamics of expansion were quite similar among the different inner ear organs at early postnatal ages, the individual sphere populations displayed very specific characteristics. All spheres derived from inner ear sensory epithelia gave rise to a subpopulation of cells that expressed a combination of marker genes reminiscent of hair cells, indicating that stem cells isolated from hair cellbearing epithelia have the intrinsic ability to grow spheres that can spontaneously generate hair cells. Spheres derived from the spiral ganglion were similar in appearance to neurospheres (Gritti et al. 1996, 2002), gave rise to neurons, and were morphologically distinct from the solid spheres generated from sensory epithelia, which were typically smaller, rounder, and less jagged. Although the spheres that we generated from the stria vascularis were self-renewing, we were not able to differentiate them into cell types that express endothelial and strial markers. We speculate that our in vitro culture conditions did not provide a suitable environment for these cells to differentiate despite our observation of morphological specialization and up-regulation of developmental genes (data not shown).

We have previously shown that sphere-generating stem cells from the vestibular sensory epithelium are pluripotent because they can give rise to many different cell types in organs derived from all three germ layers (Li et al. 2003a). Although we did not explicitly test pluripotency in this study, we argue that the stem cells that generate spheres from the organ of Corti and the spiral ganglion are at least multipotent as they give rise to multiple distinct cell types, defined by specific markers and cell morphology.

The potential of cell differentiation that we observed from sensory epithelia-derived spheres and from spiral ganglion-derived spheres is almost certainly limited by the period that we allowed the cells to differentiate and potentially by the culture conditions. Hair cells, for example, develop in a wellorganized and polarized epithelium that appears to be necessary for the growth of the hair bundle, the hair cell's mechanosensitive organelle on its apical surface. Our culture conditions do not replicate this extraordinary environment and we therefore hypothesize that in vitro-generated hair cell-like cells will only develop a certain degree of maturity. Indeed, our results support this notion as we have demonstrated remarkable similarity between the currents of vestibular stem cell-generated hair cell-like cells and the potassium currents of embryonic vestibular hair cells isolated at embryonic day 15 , which suggests that 
the stem cell-derived cells have progressed toward a young vestibular hair cell phenotype. If our stem cellderived cells continue to develop along this lineage, we would expect acquisition of an inward rectifier conductance, transient expression of a TTX-insensitive sodium conductance, and eventually, acquisition of the defining mechanotransduction conductance (Géléoc and Holt 2003). Although acquisition of a hair cell-like delayed rectifier conductance is consistent with development of a hair cell phenotype, it is not conclusive that the stem cell-derived cells are destined to become mature hair cells in vitro, even when we would provide suitable conditions. Nevertheless, our data suggest that the hair cell marker-positive cells generated in vitro acquire not only specific markers and morphological features of hair cells, but also functional characteristics reminiscent of juvenile hair cells. This conclusion is also supported by cytoplasmic Musashil protein expression in the cell types surrounding the hair cell marker-positive cells, which is a trait of developing inner ear supporting cells (Sakaguchi et al. 2004), the cells that are closely associated with hair cells.

Finally, we observed that the capacity of all auditory tissues that we analyzed to generate spheres steeply declines during the second and third postnatal weeks. At later stages, in juvenile and in adult mice, we did not observe sphere formation, which indicates that the stem cells of the auditory system disappear during the first postnatal weeks. Loss of stem cells has also been observed in the corneal epithelium of the eye, where stem cells of the limbal region disappear during postnatal life (Collinson et al. 2002). Our control experiments essentially exclude the possibility that the reduction of sphere-forming cells in cochlear tissues at older ages is caused by large decreases in cell numbers per specimen or by increased cell death during extended dissection periods. We found that total cell numbers after our isolation procedure are indeed decreased in the P42 organ of Corti and spiral ganglion, when compared to P1. Nevertheless, the degree of reduction is not sufficient to explain the massive loss of sphere formation in the organ of Corti and the spiral ganglion.

We reason that the observed loss in capacity for sphere formation is not necessarily reflected in cell loss per se because the number of cells in the maturing postnatal organ of Corti, for example, is constant. Nevertheless, in the greater epithelial ridge, a tissue adjacent to the organ of Corti and in the spiral ganglion, apoptotic cells are detectable during the first 2 postnatal weeks but not at later ages (Kamiya et al. 2001). Moreover, the greater epithelial ridge as well as the lesser epithelial ridge, a tissue juxtaposed to the outer hair cells, contain cells with proliferative capacity, as shown in cultures of the early postnatal rat cochlea (Zhai et al. 2005). It is conceivable that the greater and lesser epithelial ridges are contributing to the sphere-forming cell population; this speculation is supported by the notion that the perinatal cell loss in the greater epithelial ridge happens just about the same time when the sphere-forming cells in the organ of Corti become seriously depleted.

We hypothesize that as an alternative to the loss of stem cells, the maturing cell types in the cochlea could lose the ability to grow spheres, which might be interpreted as a loss of stem cell features. Because this loss of capacity for sphere formation is specifically happening in the postnatal auditory system and only to a certain extent in the vestibular system, we argue that it may underlie the regenerative incapacity of the adult cochlea. In this case, we would argue that the origin of the sphere forming cells in the organ of Corti could be postmitotic supporting cells, which were recently shown to be able to divide and to differentiate into hair cell-like cells in culture (White et al. 2006). It is particularly interesting that this ability to divide substantially decreases between P2 and P14 (White et al. 2006), which implies that changes in postnatal cochlear supporting cells are the reason for the diminishment of the organ's regenerative capacity, a hypothesis that is further supported by our RT-PCR expression analysis for developmental and progenitor cell markers. The diminishing stem cell features of maturing cochlear cells offer a reasonable explanation for the long known regenerative inability of the damaged cochlea. This view is supported by our observation that the expression of mRNA for inner ear developmental markers and stem/progenitor cells starkly decreases in the organ of Corti and the spiral ganglion between $\mathrm{P} 1$ and P21. In contrast, we did not detect a reduction of the same markers in the vestibular system during this time period-here we found that the markers are either equally expressed between P1 and P21 tissue or that the relative expression levels of these markers increase. We hypothesize that the sustained expression of developmental and progenitor cell markers in the vestibular sensory epithelia is an indication of the maintenance of stem cells, whereas the loss of stem cells or the loss of stem cell features in the organ of Corti is accompanied by a substantial reduction of developmental and progenitor cell marker expression. We cannot exclude that other mechanisms contribute to the differences between vestibular and cochlear stem cell populations. For example, it would be interesting to discriminate in future studies between a simple loss of stem cells (or their capacity to proliferate) and potential active mechanisms of repression, and whether these mechanisms act differently on vestibular and cochlear stem cells. 
Consequently, we speculate that our observations validate the continued exploration of treatment strategies aimed at reprogramming and rejuvenating differentiated cochlear cells. Recent promising results toward this goal have been achieved by introducing the developmentally important Atoh1 gene or by activating cell proliferation in the mature organ of Corti (Izumikawa et al. 2005; Sage et al. 2005).

Lastly, we want to note that it has recently been demonstrated that the spiral ganglion of adult humans and guinea pigs can still produce neurospheres after mitogen stimulation, albeit in low numbers (Rask-Andersen et al. 2005). We speculate that spiral ganglion stem cells probably also exist in older mice but that they are more readily detectable in single spiral ganglia specimen from guinea pigs or humans because the spiral ganglia in these mammals are substantially larger than in mouse. The absolute number of cells in spiral ganglia among these species is definitely not equal and differences also exist in cell body sizes and degree of myelination, among other factors (Nadol 1988). Nevertheless, it appears that postnatal diminishment of the mammalian cochlear stem cell population is a realistic culprit for the incapacity of the mammalian hearing organ to regenerate after damage.

\section{ACKNOWLEDGMENTS}

The authors thank Dr. H. Okano for generously supplying antibody; Dr. J.E. Johnson for supplying Math-1/nGFP transgenic mice; Drs. J. Corwin, G. Richardson, and Mark Warchol for valuable discussions. Ms. A. Müller provided expert technical help. This work was supported by grants to S.H. (DC006167), J.R.H. (DC006182) and G.S.G.G. (DC006183) from the National Institutes of Health, by a Neuroscience of Brain Disorders Award from the McKnight Endowment Fund for Neuroscience (to S.H.) and, in part, by an Albert and Ellen Grass Faculty Award (to S.H.). K.O. was supported in part by a grant from the NOHR foundation.

\section{REFERENCES}

Adler HJ, Belyantseva IA, Merritt RC Jr., Frolenkov Gi, Dougherty GW, KaChar B. Expression of prestin, a membrane motor protein, in the mammalian auditory and vestibular periphery. Hear. Res. 184:27-40, 2003.

Bermingham na, Hassan BA, Price SD, Vollrath ma, Ben-Arie N, Eatock RA, Bellen HJ, Lysakowski A, Zoghbi HY. Math1: an essential gene for the generation of inner ear hair cells. Science 284:1837-1841, 1999.

Chen P, Johnson JE, Zoghbi HY, Segil N. The role of Math1 in inner ear development: uncoupling the establishment of the sensory primordium from hair cell fate determination. Development 129:2495-2505, 2002.

Collinson JM, Morris L, Reid AI, Ramaesh T, Keighren MA, Flockhart JH, Hill RE, Tan SS, Ramaesh K, Dhillon B, West JD. Clonal analysis of patterns of growth, stem cell activity, and cell movement during the development and maintenance of the murine corneal epithelium. Dev. Dyn. 224:432-440, 2002.

Corwin JT, Oberholtzer JC. Fish n' chicks: model recipes for haircell regeneration? Neuron. 19:951-954, 1997.

Corwin JT, Finley JE, Saffer R, Gu R, Cunningham L, Xia B, WARCHOL ME. Isolation of pure living hair cell epithelia by use of thermolysin. Assoc. Res. Otolaryngol. Abstr. 18:87, 1995.

Feghali JG, Lefebvre PP, Staecker H, Kopke R, Frenz DA, Malgrange B, Liu W, Moonen G, Ruben RJ, Van de Water TR. Mammalian auditory hair cell regeneration/repair and protection: a review and future directions. Ear Nose Throat J. 77:276, 280, 282-275, 1998.

Forge A, Li L, Corwin JT, Nevill G. Ultrastructural evidence for hair cell regeneration in the mammalian inner ear. Science 259:1616-1619, 1993.

GÉlÉoc GS, Holt JR. Developmental acquisition of sensory transduction in hair cells of the mouse inner ear. Nat. Neurosci. 6:1019-1020, 2003.

GÉlÉOC GS, Risner JR, Holt JR. Developmental acquisition of voltage-dependent conductances and sensory signaling in hair cells of the embryonic mouse inner ear. J. Neurosci. 24:1114811159, 2004.

Gritti A, Bonfanti L, Doetsch F, Caille I, Alvarez-Buylla A, Lim DA, Galli R, Verdugo JM, Herrera DG, Vescovi AL. Multipotent neural stem cells reside into the rostral extension and olfactory bulb of adult rodents. J. Neurosci. 22:437-445, 2002.

Gritti A, Parati EA, Cova L, Frolichsthal P, Galli R, Wanke E, Faravelli L, Morassutti DJ, Roisen F, Nickel DD, Vescovi AL. Multipotential stem cells from the adult mouse brain proliferate and self-renew in response to basic fibroblast growth factor. J. Neurosci. 16:1091-1100, 1996.

HAFIDI A. Peripherin-like immunoreactivity in type II spiral ganglion cell body and projections. Brain Res. 805:181-190, 1998.

Heller S, Bell A, Denis CS, Choe Y, Hudspeth AJ. Parvalbumin 3 is an abundant $\mathrm{Ca}^{2+}$ buffer in hair cells. J. Assoc. Res. Otolaryngol. 3:488-498, 2002a.

Helms AW, Abney AL, Ben-Arie N, Zoghbi hy, Johnson JE. Autoregulation and multiple enhancers control Math1 expression in the developing nervous system. Development 127:11851196, 2000.

Imai T, Tokunaga A, Yoshida T, Hashimoto M, Mikoshiba K, Weinmaster G, Nakafuku M, Okano H. The neural RNA-binding protein Musashil translationally regulates mammalian numb gene expression by interacting with its mRNA. Mol. Cell Biol. 21:3888-3900, 2001.

Izumikawa M, Minoda R, Kawamoto K, Abrashin KA, Swiderski DL, Dolan DF, Brough DE, Raphael Y. Auditory hair cell replacement and hearing improvement by Atoh1 gene therapy in deaf mammals. Nat. Med. 11:271-276, 2005.

Kamiya K, Takahashi K, Kitamura K, Momoi T, Yoshikawa Y. Mitosis and apoptosis in postnatal auditory system of the $\mathrm{C} 3 \mathrm{H} / \mathrm{He}$ strain. Brain Res. 901:296-302, 2001.

Kelley MW, Talreja DR, Corwin JT. Replacement of hair cells after laser microbeam irradiation in cultured organs of corti from embryonic and neonatal mice. J. Neurosci. 15:3013-3026, 1995.

Lendahl U, Zimmerman LB, McKay RD. CNS stem cells express a new class of intermediate filament protein. Cell 60:585-595, 1990.

Li H, Liu H, Heller S. Pluripotent stem cells from the adult mouse inner ear. Nat. Med. 9:1293-1299, 2003a.

Li H, Roblin G, Liu H, Heller S. Generation of hair cells by stepwise differentiation of embryonic stem cells. Proc. Natl. Acad. Sci. U. S. A. 100:13495-13500, 2003b. 
Li H, Liu H, Corrales CE, Mutai H, Heller S. Correlation of Pax-2 expression with cell proliferation in the developing chicken inner ear. J. Neurobiol. 60:61-70, 2004a.

Li H, Liu H, Sage C, Huang M, Chen ZY, Heller S. Islet-1 expression in the developing chicken inner ear. J. Comp. Neurol. 477:1-10, 2004b.

Li H, Corrales CE, Wang Z, Zhao Y, Wang Y, Liu H, Heller S. BMP4 is involved in the generation of inner ear sensory epithelia. BMC Dev. Biol. 5:16, 2005.

Lim DJ, Rueda J. Structural development of the cochlea. In: Romand R (ed) Development of the Auditory and Vestibular Systems 2. Elsevier, New York, pp. 33-58, 1992.

Lumpkin EA, Collisson T, Parab P, Omer-Abdalla A, Haeberle H, Chen P, Doetzlhofer A, White P, Groves A, Segil N, Johnson JE. Math1-driven GFP expression in the developing nervous system of transgenic mice. Gene Expr. Patterns 3:389-395, 2003.

Malgrange B, Belachew S, Thiry M, Nguyen L, Rogister B, Alvarez ML, Rigo JM, Van De Water Tr, Moonen G, Lefebvre PP. Proliferative generation of mammalian auditory hair cells in culture. Mech. Dev. 112:79-88, 2002.

Maslov AY, Barone TA, Plunkett RJ, Pruitt SC. Neural stem cell detection, characterization, and age-related changes in the subventricular zone of mice. J. Neurosci. 24:1726-1733, 2004.

McKay R. Stem cells in the central nervous system. Science 276:66$71,1997$.

Morsli H, Tuorto F, Choo D, Postiglione MP, Simeone A, Wu DK. Otx1 and Otx2 activities are required for the normal development of the mouse inner ear. Development 126:2335-2343, 1999.

Murata J, Murayama A, Hori A, Doi K, Harada T, Okano H, Kubo T. Expression of Musashil, a neural RNA-binding protein, in the cochlea of young adult mice. Neurosci. Lett. 354:201-204, 2004.

NAdOL JB JR. Comparative anatomy of the cochlea and auditory nerve in mammals. Hear. Res. 34:253-266, 1988.

OH SH, Johnson R, Wu DK. Differential expression of bone morphogenetic proteins in the developing vestibular and auditory sensory organs. J. Neurosci. 16:6463-6475, 1996.

Rask-Andersen H, Bostrom M, Gerdin B, Kinnefors A, Nyberg G, Engstrand T, Miller JM, Lindholm D. Regeneration of human auditory nerve. In vitro/in video demonstration of neural progenitor cells in adult human and guinea pig spiral ganglion. Hear. Res. 203:180-191, 2005.

Rietze RL, Valcanis H, Brooker GF, Thomas T, Voss AK, Bartlett PF. Purification of a pluripotent neural stem cell from the adult mouse brain. Nature 412:736-739, 2001.

Rusch A, Lysakowski A, Eatock RA. Postnatal development of type I and type II hair cells in the mouse utricle: acquisition of voltage-gated conductances and differentiated morphology. J. Neurosci. 18:7487-7501, 1998.

Sage C, Huang M, Karimi K, Gutierrez G, Vollrath MA, Zhang DS, Garcia-Anoveros J, Hinds PW, Corwin JT, Corey DP, Chen ZY. Proliferation of functional hair cells in vivo in the absence of the retinoblastoma protein. Science 307:1114-1118, 2005.

Sahly I, El-Amraoui A, Abitbol M, Petit C, Dufier JL. Expression of myosin VIIA during mouse embryogenesis. Anat. Embryol. (Berl.) 196:159-170, 1997.

Sakaguchi H, Yaoi T, Suzuki T, Okano H, Hisa Y, Fushiki $\mathrm{S}$. Spatiotemporal patterns of Musashil expression during inner ear development. NeuroReport 15:997-1001, 2004.

Sanchez-Calderon H, Martin-Partido G, Hidalgo-Sanchez M. Differential expression of Otx2, Gbx2, Pax2, and Fgf8 in the developing vestibular and auditory sensory organs. Brain Res. Bull. 57:321-323, 2002.

Stone JS, Oesterle EC, Rubel EW. Recent insights into regeneration of auditory and vestibular hair cells. Curr. Opin. Neurol. 11:17-24, 1998

Suslov ON, Kukekov VG, Ignatova TN, Steindler DA. Neural stem cell heterogeneity demonstrated by molecular phenotyping of clonal neurospheres. Proc. Natl. Acad. Sci. U. S. A. 99:1450614511, 2002.

Warchol ME, Lambert PR, Goldstein BJ, Forge A, Corwin JT. Regenerative proliferation in inner ear sensory epithelia from adult guinea pigs and humans. Science 259:1619-1622, 1993.

White PM, Doetzlhofer A, Lee YS, Groves AK, Segil N. Mammalian cochlear supporting cells can divide and trans-differentiate into hair cells. Nature 441:984-987, 2006.

Xiang M, Gan L, Li D, Chen ZY, Zhou L, O’Malley BW Jr, Klein W, Nathans J. Essential role of POU-domain factor Brn-3c in auditory and vestibular hair cell development. Proc. Natl. Acad. Sci. U. S. A. 94:9445-9450, 1997.

Zhai S, Shi L, Wang BE, Zheng G, Song W, Hu Y, Gao WQ. Isolation and culture of hair cell progenitors from postnatal rat cochleae. J. Neurobiol. 65:282-293, 2005.

Zheng J, Shen W, He DZ, Long KB, Madison LD, Dallos P. Prestin is the motor protein of cochlear outer hair cells. Nature 405:149_ $155,2000 \mathrm{a}$.

Zheng JL, Helbig C, Gao WQ. Induction of cell proliferation by fibroblast and insulin-like growth factors in pure rat inner ear epithelial cell cultures. J. Neurosci. 17:216-226, 1997.

Zheng L, Sekerkova G, Vranich K, Tilney LG, Mugnaini E, Bartles JR. The deaf jerker mouse has a mutation in the gene encoding the espin actin-bundling proteins of hair cell stereocilia and lacks espins. Cell 102:377-385, 2000b. 